\title{
Challenging the accounting for goodwill in the context of a business combination
}

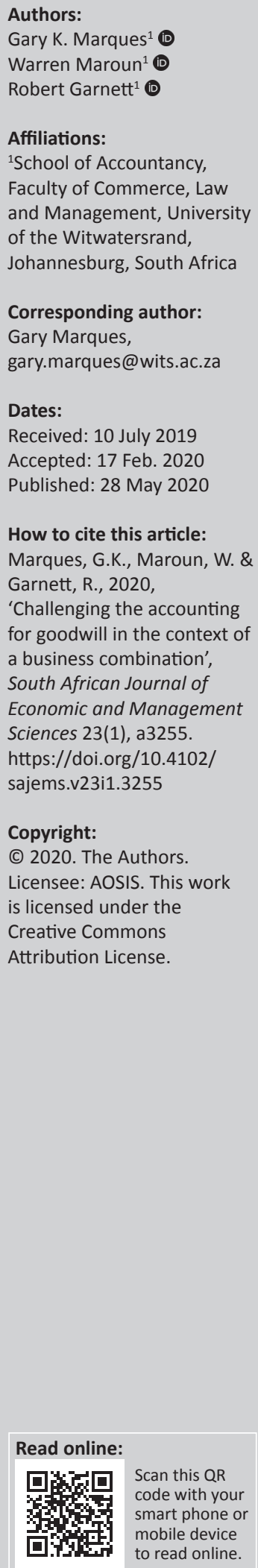

Background: The accounting for goodwill under the International Financial Reporting Standard 3 has become generally accepted as a basis for providing useful information to users of financial statements. However, the International Accounting Standards Board has conducted a review of the International Financial Reporting Standard 3, the focus of which is on the revision of the accounting for goodwill.

Aim: This article adds to the discussion on the accounting for goodwill by examining its characteristics and considering how these can be used to inform changes to its recognition and measurement.

Setting: The principles of neoliberalism and stewardship, widely regarded as key drivers of developments in financial reporting, are used to frame the accounting for goodwill.

Method: The research method makes use of correspondence analysis which is a method used to explain complex relationships in a simple diagrammatic manner. In the case of this article, the correspondence analysis is used to show how characteristics of goodwill interact with principles of neoliberalism and stewardship to reveal different perspectives on the accounting for goodwill. The sample selected was 55 chartered accountants, chartered financial analysts and business owners. The chartered accountants are in practice and academia. The reason for this is to give both an academic and practical perspective on the appropriateness of the accounting for goodwill. The reason for the inclusion of the financial analysts and business owners was to enrich the opinions received.

Results: The research finds that the accounting for goodwill needs revision.

Conclusion: A hybrid accounting model is revealed that proposes that goodwill be recognised as an asset in its own right (neoliberalism) and that it be amortised and the recognition of the effect of inefficient negotiation of the purchase price be recognised in profit or loss (stewardship).

Keywords: accountability; correspondence analysis; goodwill; neoliberalism; stewardship.

\section{Context and significance of the study}

International Financial Reporting Standard 3: Business Combinations (IFRS 3) requires goodwill arising in a business combination ${ }^{1}$ to be recognised as an asset (IFRS 3 2009). The goodwill is not amortised but is tested for impairment at least annually. Any impairments are recognised in profit or loss and cannot be reversed (IFRS 3 2009).

While this accounting treatment has become the generally accepted basis for providing useful information to users, it is not without criticism. There are a number of examples that challenge the assumption that goodwill is an asset or question inconsistencies in the initial and subsequent measurement of goodwill and other types of assets (Baldi \& Trigeorgis 2009; Ellis 2001; Eloff \& De Villiers 2015; Negash 2003). A fairly large body of work has also considered if goodwill is value relevant (Al Jifri \& Citron 2009; Lee, Kim \& Yoon 2013), the appropriateness of the models used to identify and measure subsequent impairments (see Huikku, Mouritsen \& Silvola 2017; Lee 2011) and whether or not goodwill should be amortised, contrary to the requirements of IFRS 3 (Martínez \& Rubio 2018).

In addition to the accounting treatment being challenged by researchers and academics, in May 2016, the International Accounting Standards Board (IASB) met to discuss the post-implementation findings on IFRS 3.The major finding that was highlighted was with regard to goodwill and its

1.IFRS 3 defines a business combination as "a transaction or other event in which an acquirer obtains control of one or more businesses. Transactions sometimes referred to as "true mergers" or "mergers of equals" are also business combinations as that term is used in this IFRS' (IFRS 3; A148 2009). 
impairment (IASB Discussion Paper 2016). The IASB collected data from preparers of financial statements who raised concerns around three key areas, namely the complexity of the impairment requirements, amortising goodwill to solve communication issues to users and identifying other intangible assets from goodwill. These will be discussed in more detail later in the article (IASB Discussion Paper 2016).

In this study, we turn to the core principle of accounting for transactions and balances to reflect economic substance. Our aim is to identify the essential features or characteristics of goodwill arising in a business combination and consider how these should inform the recognition and measurement of goodwill. This is done using stewardship or neoliberalism as theoretical frameworks to form an opinion on how goodwill could be accounted by examining it directly rather than following the more commonly used approach of drawing inferences about goodwill based on its value relevance or how it is subsequently tested for impairment (see Lee 2011; Kim, Lee \& Wook Yoon 2013; Ramanna \& Watts 2012).

The choice of theoretical framework is informed by the fact that tensions between accountability and neoliberalism have been identified as a defining feature of the development and application of contemporary accounting standards (see, for example, Murphy, O'Connell \& Ó'Hógartaigh 2013; Ram, Maroun \& Garnett 2016; Ravenscroft \& Williams 2009). Examples include: changes to the conceptual framework issued by the IASB (Whittington 2008) and the proliferation and application of fair value measurment (Durocher \& Gendron 2014; Zhang \& Andrew 2014). Nevertheless, to the researchers' knowledge, examples on how an alignment with either an accountability or a neoliberal agenda influences accounting treatments at the level of individual classes of assets or liabilities are rare (see Murphy et al. 2013). Consequently, an examination of the accounting for goodwill and how this accounting might change depending on the whether or not an accountability or neoliberal framework is applied offers an excellent opportunity for illustrating how theory can be used to inform normative reccomemdations for accounting for a specific type of asset. This should be relevant for both the academic and practitioner community especially because of the article's chosen method.

\section{Research question}

The research question that arises is whether the current accounting for goodwill, in the context of a business combination, ${ }^{2}$ achieves relevance and faithful representation. The reason for this is that there is a large body of published literature that challenges the current accounting practice. In addition, the IASB is in the process of developing revised accounting practices for goodwill. In this context, the researchers find it relevant to research whether preparers, academics and auditors are of the opinion that goodwill achieves relevance and faithful representation.

2 . For ease of analysis, the readers' attention is drawn to the fact that the research deals only with the accounting for goodwill aring in to business combination where a parent company acquires a $100 \%$ interest in a subsidiary. Accounting for othe types of business combinations, step-up transactions or partial acquisitions is deferred for future research.

\section{Literature review}

In this section, the prior literature, dealing mainly with the definition and measurement of goodwill, is examined to identify characteristics of goodwill. These serve as row headings (labelled ' $R$ ') in the correspondence analysis (see Appendix 1). The theoretical framework is presented in the 'Accounting policies' section. Principles of stewardship (also referred to as accountability) and neoliberalism are used to derive accounting policies for goodwill which serve as column headings (labelled ' $\mathrm{C}$ ') in the correspondence analysis. ${ }^{3}$ The interaction between the elements of goodwill (row headings) and possible accounting treatments (column headings) is used to examine alternate views on how goodwill should be recognised and measured in financial statements.

\section{Characteristics of goodwill}

The Katz Commission concluded that goodwill lacks physical substance (Steenekamp 1996). In addition, IFRS 3 defines goodwill as 'unidentifiable items purchased in a business combination' (IFRS 3 2009; Appendix 1). In this context the following characteristics are included in the correspondence analysis:

R1: Goodwill is intangible.

R2: Goodwill is unidentifiable items purchased in a business combination.

When goodwill works in combination with other assets it is often assumed to enhance the productivity of those assets. These synergistic benefits are realised in the form of superior operating performance and earnings (Jahmani et al. 2010; Ma \& Hopkins 1988). In this context the following characteristic has been included in the correspondence analysis:

R3: Goodwill represents synergies that are expected to arise as a result of a business combination.

Baldi and Trigeorgis (2009) define two approaches to the assessment of the goodwill transaction. The first is the 'residual approach' in terms of which:

Goodwill is measured as the difference between the purchase price and the fair market value of an acquired company's net tangible and identifiable intangible assets. It is thus a residual amount that cannot be directly identified. (Baldi \& Trigeorgis 2009:115).

The second is the 'excess profits approach' in terms of which:

Goodwill is the value of the combined company's profits that exceed normal earnings for a similar business. It is the present value of projected future excess earnings. (Baldi \& Trigeorgis 2009:115).

The excess profits approach is not followed by the IASB and Financial Accounting Standards Board (FASB) although the fact that goodwill is associated with excess profits (Qasim,

3.The order in which row and column headings are presented in the literature review has no specific meaning. 
Haddad \& Abughazaleh 2013) or economic value added (IFRS 3 2009, BC 326, B239) has been acknowledged by both standard setters. In terms of the excess profit approach, goodwill is the aggregation of multiple features of corporate activities that can increase a company's earning power (Baldi \& Trigeorgis 2009) or result in the generation of 'super profits' (Qasim et al. 2013). Goodwill can also be viewed as the networks built up by an acquired company's managers including, for example, relationships with suppliers, distributors and customers (Sinclair 2007). The acquiree could have established systems, new products, trained staff and innovative ways of managing its operations, all of which optimise profitability. Internal business efficiencies are defined as the reengineering of structures and processes to ensure more timely and reliable information for decisionmaking purposes (Savčuk 2007). A business combination can lead to the development of such internal efficiencies by way of the acquirer combining their internal structures with those of the acquiree. Sinclair (2007) and IFRS 3 go on to identify that goodwill can represent such internal efficiencies (IFRS 3 2009, BC 313 2009; Sinclair 2007) and in this context the following characteristic has been identified:

R4: Goodwill represents internal efficiencies or entity-specific benefits.

Ellis and Martin (2001) find that goodwill is also the control premium paid over the current operating value of the target firm taking into account the ability of the acquiring firm to benefit from or realise this value (Ellis 2001). In this context, the following characteristic has been derived:

R5: Goodwill arising on acquisition represents a payment made by the acquirer in anticipation of future economic benefits.

While the amount, timing and certainty of the future cash flows inherent in goodwill may be questionable (Eloff \& De Villiers 2015), the economic benefits represented by the goodwill balance can be attributed to the reporting entity which, by virtue of the fact that it controls the acquiree, could prevent the realisation of those benefits by other parties. ${ }^{4}$ In this context, the following characteristic has been derived:

R6: The economic benefits inherent in goodwill are restricted and cannot be realised by other parties.

The FASB released a report in 1998 on whether goodwill is an asset or an expense (Johnson \& Petrone 1998). This report noted that the IASB ${ }^{5}$ expensed goodwill. The IASB's argument for doing so was that, firstly, goodwill was not identifiable. By its very nature, it is an unidentifiable component of a business combination. Secondly, goodwill is not separable. It cannot be separated from a business and sold ${ }^{6}$ (see also

4.Example 2 in the IAS 38 illustrative Examples, discusses a patent that protects the technology used by the entity and does not allow other entities to make use of the same technology. This is an example of the way in which an asset restricts access by others (IASB 2008).

5.The IASB was the accounting standard setting body in the United Kingdom.

6.This consistent with the approach of IAS 38: Intangible Assets (IASB 2008). INTERNATIONAL ACCOUNTING STANDARDS BOARD [IASB] 2008. IAS 38: Intangible Assets. London.
IAS v38). Consequently, goodwill cannot be seen as a resource controlled by the reporting entity and should, therefore, be expensed (Johnson \& Petrone 1998). Gore and Zimmerman (2010) present a similar argument. Synergy, which is the most common explanation for the existence of goodwill, is not something that has an independent existence and should not be reported on the statement of financial position. In this context, the following characteristics have been derived:

R7: Goodwill is not identifiable and separable.

R8: Goodwill is not a resource controlled by the reporting entity.

In the absence of earnings management, IFRS 3 states that the purchase price paid by the acquirer to obtain control over an acquiree represents a genuine outflow of economic resources which forms part of the cost of the business combination (IFRS 3 2009). In this context, the following characteristic has been derived:

R9: Goodwill is the result of an outflow of economic resources of the acquirer.

Su and Wells (2014) discuss how goodwill represents the present value of expected post-acquisition performance and changes in performance (Su \& Wells 2014) which, in essence, capture the going concern element of the acquiree's business. In this context, the following characteristic has been derived:

R10: Goodwill is the going concern element of the acquiree's existing business.

The conceptual framework (IASB 2010) defines an asset as a 'present economic resource controlled by the entity as a result of past events'. IFRS 3 requires goodwill to be recognised as an asset (IFRS 3 2004b). The rationale for this accounting treatment is found in the Basis for Conclusions on IFRS 3 which states:

The FASB also considered evidence about the relevance of goodwill provided by a number of research studies that empirically examined the relationship between goodwill and the market value of business entities. Those studies generally found a positive relationship between reported goodwill of entities and their market values, thereby indicating that investors in the markets behave as if they view goodwill as an asset. (IFRS 3 2004b, BC327)

Ellis and Martin (2001) define goodwill as the difference between a company's net assets at book value and market value. In other words, goodwill is seen as the difference between a company's equity as reflected in the financial statements and the market value listed on a securities exchange (Ellis 2001). In addition, Negash (2003) and Eloff and De Villiers (2015) found that there is an association between intangible assets, including goodwill, and the market value of the company to which it relates (Eloff \& De Villiers 2015; Negash 2003). As a result, the usefulness of financial statements is undermined by the gap between the book and market value of a firm (Negash 2003), something that can be partially addressed by recognising goodwill arising on a business combination (Eloff \& De Villiers 2015). 
In this context the following characteristic is included in the correspondence analysis:

R11: There is a relationship between the market value of a business and goodwill.

Linked to the point that goodwill is unidentifiable, Shalev, Zhang and Zhang (2013) discuss how goodwill has the characteristics of a 'dumping ground' for other identifiable assets arising as a result of the acquisition of the acquiree. This is because goodwill is not amortised in the same way as other intangible assets creating an incentive to incorporate these intangible assets as part of goodwill (Shalev et al. 2013). In this context, the following characteristic has been derived:

R12: Goodwill may incorporate identifiable unrecognised assets or recognised under-valued assets, as part of an earnings management exercise.

Gore and Zimmerman (2010) and Bugeja and Gallery (2006) question the accounting for goodwill as an asset in terms of existing accounting standards. They identified that goodwill which is more than two years old is no longer value relevant to market participants (Bugeja \& Gallery 2006). This is because the benefits of an acquisition are increasingly reflected in normal operations and any additional value is captured in earnings rather than goodwill (Bugeja \& Gallery 2006). This links with the excess profits approach. As explained earlier, this describes goodwill as being the present value of excess earnings measured with reference to a benchmark entity (Baldi \& Trigeorgis 2009). Over a period of time, the excess earnings will begin to reflect as normal earnings. In addition, competitors will enter the market to share in excess returns leading to a reduction in earnings. Therefore, the excess profits reduce and the value of goodwill tends to zero (Baldi \& Trigeorgis 2009). In this context, the following characteristic has been derived:

R13: The economic benefits inherent in goodwill are realised within a short period after acquisition.

Ma and Hopkins (1988) and Jahmani et al. (2010) explain that goodwill can be seen as a type of 'earnings reserve' which represents the future cash flow potential of the business combination either due to an increase in cash inflows or cost savings as synergistic benefits are realised (Jahmani et al. 2010; Ma \& Hopkins 1988). In this context, the following characteristic has been derived:

R14: Goodwill has the ability or potential to contribute, directly or indirectly, to future cash flows.

This premium is paid to obtain access to the acquiree's systems, know-how and processes and to generate economic benefits. Alternatively, it is paid to control the flow of products or services from a competitor, restrict access to a market or protect a particular line of business (Ellis 2001). In this context, the following characteristic has been derived:

R15: Goodwill is a form of a defensive intangible asset.

The characteristics discussed in the preceding paragraphs form the basis of the row headings (R1 - R15) in the correspondence analysis (goodwill matrix) in Appendix 1.

\section{Accounting policies}

\section{History of the accounting for goodwill}

Over time, different accounting policies for goodwill have emerged. Ding et al. (2008) summarise these differences into four stages (Ding et al. 2008). The four stages in Ding's model are the 'Static', 'Weakened Static', 'Dynamic' and 'Actuarial'. The Static phase saw the balance sheet as a representation of the liquidity of a business. As a result, all assets were measured at a liquidation value (Ding et al. 2008). Goodwill was not seen as having value that could be realised directly and it was, therefore, expensed. This stage ended during the early 1900s with the start of the Weakened Static phase. This emphasised the going concern assumption and accounted for goodwill as a direct debit to equity. Around the mid-1970s to the early 1980s the Dynamic phase saw goodwill capitalised as an asset based on the view that it represented economic benefits expected to be realised in the future rather than a reduction to reserves (equity). Goodwill was amortised over a 'random useful life' which varied from 10 to 40 years. ${ }^{7}$ The fourth stage, which characterises current accounting practice, is the Actuarial phase (Ding et al. 2008).

The move to the Actuarial phase was due to the FASB taking the position that the amortisation of goodwill over a random useful life was not conceptually sound (SFAS 142 2001; Ding et al. 2008). The FASB concluded that goodwill arises due to integrated activities between two or more companies. By amortising goodwill over a useful life, this fact is ignored as only one of the companies (the acquiree or the acquirer) is considered when making the useful life assessment rather than all of the companies involved in the business combination (SFAS 2001, 142). To correct this, the FASB resolved that goodwill has an indefinite useful life and is assessed for impairment annually and when any indicators of impairment arise (SFAS 2001, 142). To avoid the revaluation of goodwill and, indirectly, the capitalisation of internally generated goodwill, an impairment of goodwill cannot be reversed (Baldi \& Trigeorgis 2009; SFAS 2001, 142).

The IASB followed a comparable approach when replacing IAS 22 with IFRS 3 (Eloff \& De Villiers 2015). The IASB also removed the accounting requirements for goodwill in IAS 38 because goodwill does not meet the separability and identifiability criteria required to meet the definition of an intangible asset (Eloff \& De Villiers 2015).

\section{Current accounting for goodwill}

In terms of IFRS 3 goodwill is defined as:

An asset representing the future economic benefits arising from other assets acquired in a business combination that are not individually identified and separately recognised. (IFRS 3 2009, A148)

Subsequently goodwill is not amortised but assessed, at least annually, for impairment (IFRS 3 2009). This is consistent 7.IFRS for small and medium enterprises still amortises goodwill over a maximum useful life of 10 years (IASB 2015). 
with the Actuarial phase described in (Ding et al. 2008). Stewardship and neoliberalism are used as theoretical frameworks to evaluate this accounting policy in more detail and derive alternate perspectives on accounting for goodwill.

\section{Stewardship}

Accounting has its genesis in the need to 'keep account' in order to hold individuals accountable. This function continues to be relevant in contemporary organisations (Hopwood 1987; Ravenscroft \& Williams 2009). Murphy et al. (2013), for example, analyse the accounting landscape in relation to social jurisprudence. They identify a 'living law' rooted firmly in the principles of accountability and stewardship which, in turn, influences the development of accounting systems. From a classic agency perspective, the information asymmetry between management and shareholders can also be seen as requiring an accounting function to ensure monitoring and control (Watts \& Zimmerman 1979; Young 1998). As explained by Gjesdal (1981) and Ding et al. (2008) financial statements are not used primarily for internal management by the owner-manager but by a separate body of shareholders concerned with evaluating managers' performance and overall corporate stewardship. Ravenscroft and Williams (2009) confirm this view, arguing that, while accounting assists an organisation by presenting facts that can be used internally, it provides the primary basis for gauging management's performance.

The accountability agenda leads to a clear focus on objective measures of financial position and performance and an emphasis on determination and allocation of costs (Gjesdal 1981; Ravenscroft \& Williams 2009; Whittington 2008). The allocation of the cost of a business combination giving rise to goodwill informs users about what has been purchased. This is consistent with a residual approach to accounting for goodwill which conceptualises goodwill as the purchase consideration paid for obtaining control over the different elements of the acquiree rather than something that can be identified and measured directly (Baldi \& Trigeorgis 2009).

The current accounting under IFRS 3 reflects elements of this residual framing of goodwill in the sense that goodwill is defined as the difference between the fair value of the consideration paid to obtain control over the acquiree and the fair value of the acquiree's net identifiable assets (see IFRS 3 2009). In addition, goodwill is defined as the other assets acquired in a business combination that are not individually identified and separately recognised (IFRS 3 2009). From a stewardship perspective, these benefits cannot be specifically identified and realised and, as a result, should be measured indirectly.

C1: Goodwill is recognised initially and measured indirectly as the difference between fair value of the consideration paid and the net asset value of the acquiree.

More conservatively, it can be argued that the synergistic benefits represented by goodwill should be expensed.
They represent an over-payment for the identifiable component of a business for which management should be held accountable (Ravenscroft \& Williams 2009; Whittington 2008):

C2: The difference between the purchase price and net assets should be accounted for as an expense.

In terms of an accountability paradigm, cost is a relevant measurement basis. It provides a value for evaluating measures of financial performance in order to determine how managers have generated returns from the capital made available by shareholders without the effect of market forces (or other factors) over which managers have no direct control (Maroun \& Garnett 2014). In essence, cost precludes changes in fair value being recognised as unrealised gains in income. This is an example of the application of prudence (Whittington 2008). With regard to business combinations, it would be prudent to measure the transaction at its cost and allocate the cost to goodwill and the other assets acquired. Prudence would then imply that, if the cost of the combination is assessed subsequently and is overstated, an impairment should be recognised to adjust the cost accordingly. The principle of prudence is a key concept of stewardship, and can ameliorate the reliability of financial reporting (Whittington 2008). In this context, the following accounting policy themes are used in the correspondence analysis:
C6: Recognising post-acquisition increases in goodwill is imprudent.

C7: Goodwill should be tested for impairment.

As explained by Ding et al. (2008), there have been a number of different accounting policies for goodwill. Johnson and Petrone (1998) also discuss this fact in their commentary on whether goodwill is an asset. They discuss that the definition of an asset cannot be applied to goodwill and that much further debate is required. This debate arises due to the fact that for an economic resource to be controlled by an entity from which economic benefits are expected to flow, such asset must be separable and identifiable (Ciprian et al. 2012). Goodwill, by its definition, is those assets that are not separately identifiable (IFRS 3 2009). The inference from the context of Johnson and Petrone's argument is that goodwill can be expensed (Johnson and Petrone 1998). This accounting treatment is in line with the Static phase. Subsequently, the accounting standard setting bodies, such as the IASB and FASB, published standards related to the accounting for goodwill. An example would be FRS 10: Goodwill and Intangible Assets, which introduced the concept that goodwill be amortised over a period of no longer than 10 years $^{8}$ (IASB 1997). More recently, the IASB published IFRS for SMES which allows for the amortisation of goodwill over a useful life of also no more than 10 years (IASB 2015). These two accounting policies are consistent with the Random Useful Life phase and suggest that:

C9: Goodwill should be amortised over a fixed maximum period. 8. In certain circumstances FRS 10 allows for the useful life to be extended to 20 years (IASB 1997). 


\section{Neoliberalism}

From the start of the 21st century, financial reporting has experienced a fundamental shift characterised by a neoliberal paradigm (Murphy et al. 2013; Ravenscroft \& Williams 2009; Zhang \& Andrew 2014). At the heart of neoliberal accounting is the 'information metaphor' which sees the primary purpose of financial reporting as the provision of useful information to users (Ravenscroft \& Williams 2009; Whittington 2008). In addition, neoliberalism places emphasis on the amount, timing and certainty of future cash flows rather than the relevance of past transactions. As a result, prudence and cost give way to financial relevance and the use of fair values (Whittington 2008).

In the context of a business combination, neoliberals would require all assets and liabilities to be measured directly at fair value. In keeping with this view, goodwill should be measured initially at fair value as an asset in its own right rather than as a residual value (consider Ravenscroft \& Williams 2009; Whittington 2008; Zhang \& Andrew 2014). This may require the use of complex estimation techniques, even though the measure of goodwill is less reliable:

C5: Goodwill should be measured at fair value as an element in its own right.

From a neoliberal perspective, carrying goodwill at its fair value provides the most relevant information to current and future providers of financial capital. Any difference between the direct measure of goodwill at fair value and the indirect measure proposed under an accountability regime represents overperformance or underperformance relative to a marketbased measure and is, as a result, recognised immediately as a gain or loss:

C10: Differences between fair value of goodwill (measured directly) and the amount determined using IFRS 3 (an indirect measure) should be recognised in profit or loss at acquisition date.

Changes in the market or fair values of assets and liabilities are important for understanding an organisation's ability to generate future cash flows (Baldi \& Trigeorgis 2009; Beatty \& Weber 2006; Chambers 2007; Ravenscroft \& Williams 2009; Whittington 2008; Zhang \& Andrew 2014). This means that changes in value should be accounted for even if these are unrealised or can only be estimated:

C8: Changes in the value of goodwill after initial recognition should be accounted for.

Changes in the fair value of goodwill are, in essence, part of comprehensive income and essential for providing a more complete measure of financial performance for the period under review (see Whittington 2008). Comprehensive income is the variation in a company's net assets from non-owner sources during a specific period (IASB 2007, IAS 1). The reason why comprehensive income would be used is because changes in the fair value of goodwill would be a variation in the net assets. The source of such change would be due to changes in the market value of the company's share price, which is a non-owner source. The reason for this is that such changes would be outside the control of management of the entity. This is the case even if there is significant volatility in the fair value measure (Ram et al. 2016). Stewardship would preclude volatility due to the 'noise' it creates in the financial statements, as well as the fact that changes in the fair value are not under management's control (Ravenscroft \& Williams 2009). From a neoliberal perspective, changes in the quantum of realised and unrealised gains are important because they help predict an organisation's ability to generate future cash flows. In this context, the following accounting policy themes are used in the correspondence analysis:

C3: Volatility in market and asset prices should not preclude recognition of goodwill.

C4: Volatility in market and asset prices should not preclude measurement of goodwill.

The accounting policies form the basis of the column headings (C1 - C10) in the correspondence analysis (goodwill matrix) in Appendix 1.

\section{Balancing neoliberalism and accountability}

Rather than seeing neoliberalism and stewardship as opposing forces, these theoretical perspectives can be meaningfully employed to shed light on how transactions and events can be 'portrayed' in financial statements. More specifically, the two paradigms are used to propose different accounting policies for goodwill and compare the resulting accounting to the characteristics of goodwill. In turn, this will assist in evaluating the appropriateness of the current accounting for goodwill.

\section{The International Accounting Standards Board's International Financial Reporting Standards 3 post-implementation project}

As discussed above, the IASB met in May 2016 to discuss post-implementation findings from the implementation of IFRS 3. Data were collected from preparers of financial statements who raised concerns around three key areas, namely (IASB Discussion Paper 2016):

1. The complexity of the impairment requirements.

2. Proposal to amortise goodwill to solve communication issues to users.

3. Identifying other intangible assets from goodwill.

The reason for the second key issue is due to the first key issue (IASB Discussion Paper 2016). The preparers of the financial statements have expressed that the impairment of goodwill calculation is complex and leads to errors being made. This is supported by prior research which has indicated that this calculation contains a number of subjective estimates and can be manipulated or purely have errors (IASB Discussion Paper 2016). Instances have arisen where goodwill should have been impaired, and was not, which reduces the 
usefulness of the financial statements (Beatty \& Weber 2006; Jahmani et al. 2010; Jordan \& Clark 2004). The preparers of financial statements have provided feedback to the IASB that to eliminate the risk of impairments not being recognised timeously, goodwill should be amortised. Therefore the second key issue addresses the first key issue. C9 above is consistent with the views of these preparers as C9 specifies that goodwill should be amortised over a fixed period.

The third issue raised by the IASB is that previously unrecognised assets and liabilities that are identifiable at acquisition are not being recognised. This results in these values being capitalised to goodwill, thus misstating the goodwill balance (IASB Discussion Paper 2016). In the case of identifiable intangible assets, these assets are not amortised over a useful life (IASB Discussion Paper 2016). Instead they form part of goodwill and are not amortised but only assessed annually for impairment. This supports R12 and Shalev et al.'s (2013) research that goodwill becomes a 'dumping ground' for other intangible assets as part of an earnings management exercise. The amortisation of these intangible is not reflected in profit and loss and so profit and loss is manipulated.

\section{Methods}

\section{Inductive thematic analysis}

In the first phase, an inductive thematic analysis was carried out. Research papers, technical papers on goodwill and current and previous accounting standards pertaining to goodwill were purposefully selected by the lead researcher and analysed for key themes. As the intention is not to quantify or generalise results, a random sampling technique was unnecessary. Instead, validity and reliability were ensured by the sampling relevant academic and professional literature from reputable databases such as JSTOR, Social Science Research Network and Wiley until saturation was achieved.

In total 90 indexed journals and 5 professional accounting repositories were identified. Structured searches were conducted for all of the sources to identify articles, technical papers or professional reports that referred to goodwill in their title, key words, abstract or HTML files (when available). Each source was then examined in detail by the lead researcher to identify characteristics of goodwill, views on how to account for goodwill and any criticisms of the accounting standards applicable at the time.

In total 118 pieces were reviewed with journal articles constituting the majority (approximately 85\%).

Each article or report was coded by the lead researcher. In essence, each publication was analysed for similarities which were then aggregated into recurring themes or open codes (Guest et al. 2013; Leedy \& Ormrod 2014). Themes relating to the characteristics of goodwill identified during the coding process are discussed in 'Characteristics of Goodwill' section and themes dealing with the possible approaches for accounting for goodwill are discussed in the 'Accounting policies' section.

The lead researcher assumed responsibility for the coding process to ensure consistent data analysis. The coding was, however, reviewed by the support researchers who independently examined the coding of the prior literature and identification of row and column headings to ensure accuracy and consistency. In total, 15 row and 10 column headings were identified resulting in a $10 \times 15$ matrix presented in Appendix 1 (Table 1 A-1). The orders of the entries in the correspondence table and assigned symbols have no specific meaning.

It should be noted that the coding was inherently subjective. This is not, however, seen as a validity concern because of the exploratory nature of the study. Scientific text analysis offered a more objective method but an interpretive coding exercise, informed by the prior literature on goodwill and a clearly defined theoretical framework, avoided data reduction and loss of exploratory potential (Guest et al. 2013; Saunders, Lewis \& Thornhill 2009).

\section{Correspondence analysis}

In the next phase, a correspondence analysis was carried out with 55 accounting experts. These included auditors, practitioners and standard setters. The practitioners included chartered accountants and direct investors or shareholders. ${ }^{9}$ The intention in canvassing a broad range of respondents was to add to the robustness of the study by ensuring that varied perspectives were included in the final analysis.

As the aim of this study is not to determine an optimal result, a smaller sample size is justifiable and consistent with those used in comparable studies (Kudlats, Money \& Hair 2014; Maroun 2015; Ram et al. 2016). The article also deals with a technical analysis of goodwill and its accounting rather than how a broad group of stakeholders understand goodwill. For this reason, only individuals with a detailed understanding of financial reporting were engaged.

\section{Choice of method}

The use of correspondence analysis is appropriate as this technique is becoming increasingly popular as an exploratory tool, rather than as a means of pure statistical analysis (Beh 2004). The research in this article is exploratory and uses a correspondence analysis to 'map' possible approaches to accouting for goodwill. Correspondence analysis has been used successfully in marketing (Bendixen 1996; Hoffman \& Franke 1986), psychology (Doey \& Kurta 2011) and tourism (Chen 2001) to explain otherwise complex relationships in a simple diagrammatic manner.

9.Respondent types are equally represented. An un-tabulated series of chi-squared tests of association revealed no differences in pattern of responses between the types of respondents. This is probably due to the fact that all of the respondents types of respondents. This is probably due to the fact that all of the respondents
have a detailed understanding of the nature of goodwill and existing financial reporting standards. 
In the case of this research, the correspondence analysis is used to show how characteristics of goodwill interact with principles of neoliberalism and accountability to reveal different perspectives on the accounting for goodwill. This is done using an easy-to-interpret correspondence plot which generates findings that can be readily understood by both academics and practising accountants (consider Broadbent \& Unerman 2011).

This method's ability to summarise the interaction among variables (included in row and column headings in a correspondence matrix) and reveal relationships that may not be obvious from a correlation test or regression model is why it has been used.

\section{Data collection and analysis}

The researcher contacted respondents directly and informed them of the purpose and nature of the research. They were provided with a brief explanation of the technique and the final correspondence table (Appendix 1). As an added quality safeguard, the correspondence table was piloted with accounting academics to ascertain its validity. The participants were asked to mark with an ' $X$ ' cells where they felt that the characteristics of the goodwill (rows) correspond positively with the accounting policies (columns). Each cell did not need to be marked and could be left blank depending on participants' opinions.

Each response and non-response was assigned a value of 1 or 0 so that the data was standardised for analysis. The results were then compiled into a single frequency table. The completed frequency table was used to construct a correspondence plot (Kudlats et al. 2014).

Firstly, the masses of the rows and columns were determined, including the column and row profiles (Habib et al. 2012). Next, these values were used to determine the inertia of each point in the table (Maroun, Turner \& Sartorius 2011; Ram et al. 2016). Each data point in the analysis has a set of coordinates, assigning it a location in a visual map. These points are a certain distance away from the average of all the data points or the centroid (Kudlats et al. 2014). The maximum number of dimensions is given by the degrees of freedom. For ease of interpretation, only two dimensions are used for the analysis (Kudlats et al. 2014).

Principal component analysis was used to ascertain the coordinates of each data point. Summary statistics and a correspondence plot were generated and interpreted by the researchers (Doey \& Kurta 2011; Habib et al. 2012; Kudlats et al. 2014). This involved a visual inspection of the plot to determine the relationship between the characteristics and accounting policies focusing only on significant row and column points (Kudlats et al. 2014).

In order to determine the significance of the goodwill characteristics and accounting policy themes, the total inertia is allocated equally but separately to the characteristics and themes to determine the average inertia per characteristic and theme (Kudlats et al. 2014; Maroun 2015; Ram et al. 2016). A characteristic or theme is significant where its inertial contribution exceeds the average inertia per characteristic or theme (Kudlats et al. 2014; Maroun 2015; Ram et al. 2016). Once the significant accounting policy themes were identified, the coordinates of these accounting themes were then explored in greater detail. Based on whether the accounting policy theme was significant in Dimension 1 or Dimension 2, the accounting policy themes were assigned to a dimension. Significance in Dimension 1 indicated that the respective data point lay on the $x$-axis and significance in Dimension 2 indicated that it lay on the $y$-axis. The sign (positive or negative) of the coordinate indicated whether it was on the positive or negative side of the applicable axis.

The axes were labelled by the lead researcher according to the accounting policy themes that provided the best explanation of the respective dimensions. ${ }^{10}$ The loading of goodwill characteristics on each axis (taking into account the strength of correlations and inertial contribution) provides an interpretive perspective of how the characteristics of goodwill influence the selection of accounting polices (adapted from Kudlats et al. 2014; Maroun et al. 2011; Ram et al. 2016).

\section{Ethical consideration}

Wits University granted the ethics clearance for the authors to contact the samples from which the data were collected. Wits University has a well-established governance structure and ethics committee. Ethical Clearance Number: CACCN/1122, 15 July 2018.

\section{Results \\ Descriptive statistics}

Summary descriptive statistics are presented in Table 1.

At 126 degrees of freedom, the chi-squared statistic of 250.45 is in excess of the critical value (at a 1\% level) providing evidence to suggest that there is a statistically significant dependence between the rows and columns. The total inertia is explained by nine dimensions. Table 1 also shows that the first two dimensions (which are the $x$-axis and $y$-axis in the final correspondence plot) account for $81 \%$ of the total inertia and for most of the exploratory potential of the graphical plot. This confirms the appropriateness of using only two dimensions for the analysis. ${ }^{11}$ While the inclusion of more dimensions will increase the percentage of the inertia explained, the result would be difficult to interpret (Hair et al. 1998) with only a marginal increase in exploratory detail.

10.This introduces a degree of subjectivity which is in keeping with an interpretive research design. The labelling of the axes was, however, reviewed by the support researchers and presented at two accounting conferences to ensure reasonability.

11.This is consistent with the approach followed in other exploratory studies (Bendixen 1996; Doey \& Kurta 2011; Hoffman \& Franke 1986; Kudlats et al. 2014) 
TABLE 1: Descriptive statistics.

\begin{tabular}{lc}
\hline Variable & Value \\
\hline Active rows & 15 \\
Active columns & 10 \\
Number of observations & 1923 \\
Pearson chi $^{2}(126)$ & 250.45 \\
Probability $>$ chi $^{1}$ & 0 \\
Total inertia & 0.1302 \\
Number of dimensions & 2 \\
Explained inertia $(\%)$ & 80.99 \\
\hline
\end{tabular}

Only those characteristics and accounting themes that make an above average inertial contribution are included in the correspondence plot (Figure 1) to ensure ease of interpretation. Appendix 2 and Appendix 3 provide test statistics for the goodwill characteristics (rows) (see Appendix 2 Table A-2) and accounting policy themes (columns) used to identify the statistically significant elements. In this regard, the characteristics of goodwill (Rs) with a contribution exceeding $7 \%{ }^{12}$ and accounting themes (Cs) (see Appendix 3 Table A-3) with a contribution exceeding $10 \%{ }^{13}$ have been included in the correspondence plot. ${ }^{14}$

\section{Analysis}

\section{Naming the axis}

Taking into account the sign of each accounting policy theme (column headings), its correlation coefficient and inertial contribution (refer to Appendix 2 and Appendix 3), the $x$-axis and $y$-axis are named. This is done by examining and analysing the similarities in each of the grouped accounting policy themes.

The positive $x$-axis is named 'Neoliberalist basis of measurement'. This is because C5 is the accounting policy theme that loads on that axis, which requires goodwill to be recognised as an asset in its own right and measured at fair value in line with a neoliberal framing.

The negative $x$-axis is named 'Stewardship basis of measurement'. This is because C2 and C10 load on this axis. The former requires that goodwill be expensed. In essence, it represents an over-payment for the net assets of the acquiree which will not necessarily be recovered in the future. To hold management accountable, the amount is included as profit or loss to show a reduction in total performance for the current period (consider Baldi \& Trigeorgis 2009; Eloff \& De Villiers 2015; Ravenscroft \& Williams 2009; Whittington 2008). Similarly, C10 is concerned with accounting for differences between a direct and an indirect measure of goodwill as a gain or loss in order to provide a measure of management's performance when executing the business combination (see Maroun \& Garnett 2014).

\footnotetext{
$12.100 \%$ divided by the 15 characteristics to determine the average inertia for characteristics.

$13.100 \%$ divided by the 10 accounting policy themes to determine the average inertia for the accounting policy themes.

14.All such items are denoted with $a^{\prime *}$ '.
}

The positive $y$-axis is named 'Subsequent measurement'. This is because C6, C7 and C9 load on this axis. C6 states that recognising post-acquisition increases in goodwill is imprudent and is consistent with the existing provisions in IFRS 3 which does not permit increases in the value of goodwill to be accounted for after the acquisition date (Ding et al. 2008; IFRS 3 2004b; Whittington 2008). Similarly, C7 is aligned with the stewardship view and provisions of IAS 36 which state that goodwill should be tested for impairment annually and whenever there are indicators to suggest that the asset may be impaired (IASB 2004a, IAS 36). C9 is derived from FRS 10 which required goodwill to be amortised over some form of a useful life (IASB 1997). This is consistent with the stewardship-based approach of allocating the cost of an asset over an expected useful life in order to match revenues and expenses (Ding et al. 2008; Whittington 2008). The aim is to include a measure of the cost of goodwill 'consumed' in each period which can be contrasted with the revenues generated and provide a basis for gauging how well managers have deployed the resources entrusted to them in order to generate returns.

The negative $y$-axis is named 'Volatility in initial recognition and measurement'. This is because C3 loads on this axis. C3 states that the recognition of goodwill should not be precluded because of volatility in asset and market prices. As explained in the 'Characteristics of goodwill' section, this is in keeping with the neoliberal position that the inclusion of volatile changes in fair value in comprehensive income enhances users' understanding of the nature of expected cash flows rather than undermining the usefulness of financial statements (Ram et al. 2016; Whittington 2008). Volatility in subsequent measurement should also not preclude the recognition of an asset (Barth 2006).

\section{Detailed analysis of the axes}

Each row-point's sign, correlation coefficient and chi-squared value-variance are then used to position the points (characteristics) on the positive or negative $x$-axis and $y$-axis (Bendixen 1996; Maroun et al. 2011). The sign of any point is only indicative of its positioning relative to the axes and does not, in or of itself, indicate a favourable or unfavourable finding (see Appendix 2 and Appendix 3).

Figure 1 represents the correspondence plot based only on statistically significant relationships (contributions in excess of the average inertia). The results were stratified into four quadrants based on the coordinates in each dimension (see the 'Accounting policies' section). For example, R11 was statistically significant in Dimension 1 (contribution of $8.7 \%$ exceeded the average of $7 \%$ ) and the coordinate was positive meaning that it lies on the positive $x$-axis.

\section{The $y$-axis}

$\mathrm{R} 9$ and R11 are loaded on the negative $y$-axis. R9 deals with the fact that goodwill represents an outflow of economic resources of the acquirer. R11 defined the relationship 


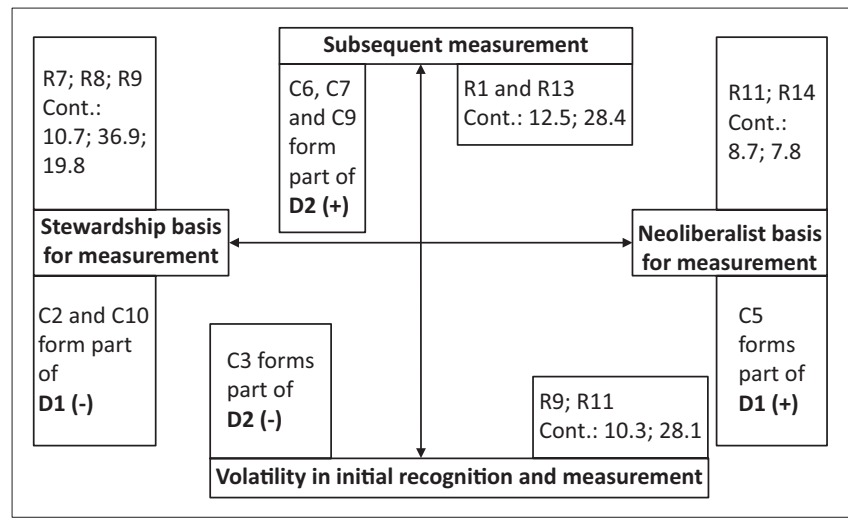

FIGURE 1: Correspondence plot.

between the market value of a business and the calculated goodwill. The correlations suggest that the volatility in the value of goodwill after a business combination does not detract from the fact that there has been an initial outflow of economic resources which should be accounted for upon initial recognition. This points to a neoliberal leaning in the sense that uncertainty inherent in future cash flows affects the measurement of the transaction rather than assessment of whether or not the conceptual framework's recognition criteria have been satisfied (see Barth 2006).

R1 and R13 load predominately on the positive $y$-axis. R13 deals with the fact that the economic benefits inherent in goodwill are consumed within a short period of time (Baldi \& Trigeorgis 2009; Bugeja \& Gallery 2006; Gore \& Zimmerman 2010). The correlation between R13 and C6, C7 and C9 suggests that the economic benefits inherent in goodwill are temporary; goodwill does not have perpetual earning power with the result that it is necessary to account for the 'consumption' of the benefits associated with the business combination as these are realised. This also supports the IASB's findings from their post-implementation review of goodwill that goodwill should be amortised.

R1 defines the goodwill transaction as giving rise to an intangible asset (Steenekamp 1996). The fact that goodwill is unidentifiable and inseparable reaffirms the view that economic benefits inherent in the asset are probably enjoyed over a short period of time. In addition, because goodwill is similar to other intangible assets, respondents appear to be of the view that it should be treated in the same way as the majority of intangibles that IAS 38 requires to be amortised to a nil residual value.

\section{The $x$-axis}

R7, R8 and R9 load on the negative $x$-axis. The fact that goodwill is not identifiable or separable (R7) and not necessarily a resource that is directly controlled and managed by the reporting entity (R8) suggest that it should be expensed on initial recognition (Johnson \& Petrone 1998). This is reaffirmed by the fact that there has been an outflow of economic resources (R9) which, as discussed earlier, may not necessarily result in an increase in future cash flows as the benefits of the business combination are realised. This points to a relatively prudent assessment of the ability of goodwill to contribute to improved financial returns in the long term and is in line with an accountability-based view which would preclude the recognition of an asset under conditions of uncertainty (Gjesdal 1981; Johnson \& Petrone 1998; Whittington 2008).

R11 and R14 load on the $x$-axis. This accounting is seen as appropriate because of an established relationship between goodwill and the market value of the acquiree (R11) as suggested by the prior research (see Ellis 2001; Eloff \& De Villiers 2015; Negash 2003) and the basis for conclusions accompanying IFRS 3 (IASB 2004b, BC 327). The fact that goodwill has a non-zero value means that it is more than some form of speculative element. It is grounded in an economically rational assessment of the value of the underlying business being acquired (Shalev et al. 2013) and may be viewed by investors as if it were a directly observable asset (IFRS 3 2004b). This is true, irrespective of whether the contribution made by goodwill to an organisation's future cash flows are direct or indirect (R14). Any uncertainty in the amount and timing of future cash flows associated with the goodwill would be taken into account in the market-based measure rather than the decision to recognise goodwill (Barth 2006; Jahmani et al. 2010; Ma \& Hopkins 1988) in keeping with a neoliberal stance (Ravenscroft \& Williams 2009; Whittington 2008).

\section{Conclusion}

Possible accounting treatments are summarised in Figure 2 based on the results discussed in the 'Results' section.

Figure 2 indicates that goodwill can either be expensed or capitalised. In the case of expensing goodwill, stewardship is the applicable framework. Stewardship holds management responsible for inconsistencies in the bargaining process. Expensing differentials between the value and the purchase price of the acquired business is a method of recording the cost of inefficient acquisitions where the amount paid for the business exceeds the net expected cash flows from identifiable net assets (Ding et al. 2008; Gjesdal 1981; Whittington 2008).

In recognising goodwill as an asset, elements of neoliberalism are evident at initial recognition. In particular, volatility in asset values should not preclude the recognition of goodwill (Ram et al. 2016; Whittington 2008). In addition, at initial recognition, goodwill should be measured as an asset in its own right at fair value and not as a residual. This is in contrast to the approach prescribed by IFRS 3 and in favour of a type of excess profit methodology for assigning a value to goodwill directly (see Baldi \& Trigeorgis 2008). Any difference between a direct and residual measure of goodwill is accounted for in profit or loss. This draws on principles of stewardship. Management should be accountable for potential inefficiency when negotiating the business combination or favourable bargaining techniques, something which may be captured by the direct and residual value differential (Gjesdal 1981; Watts \& Zimmerman 1978; Whittington 2008). 


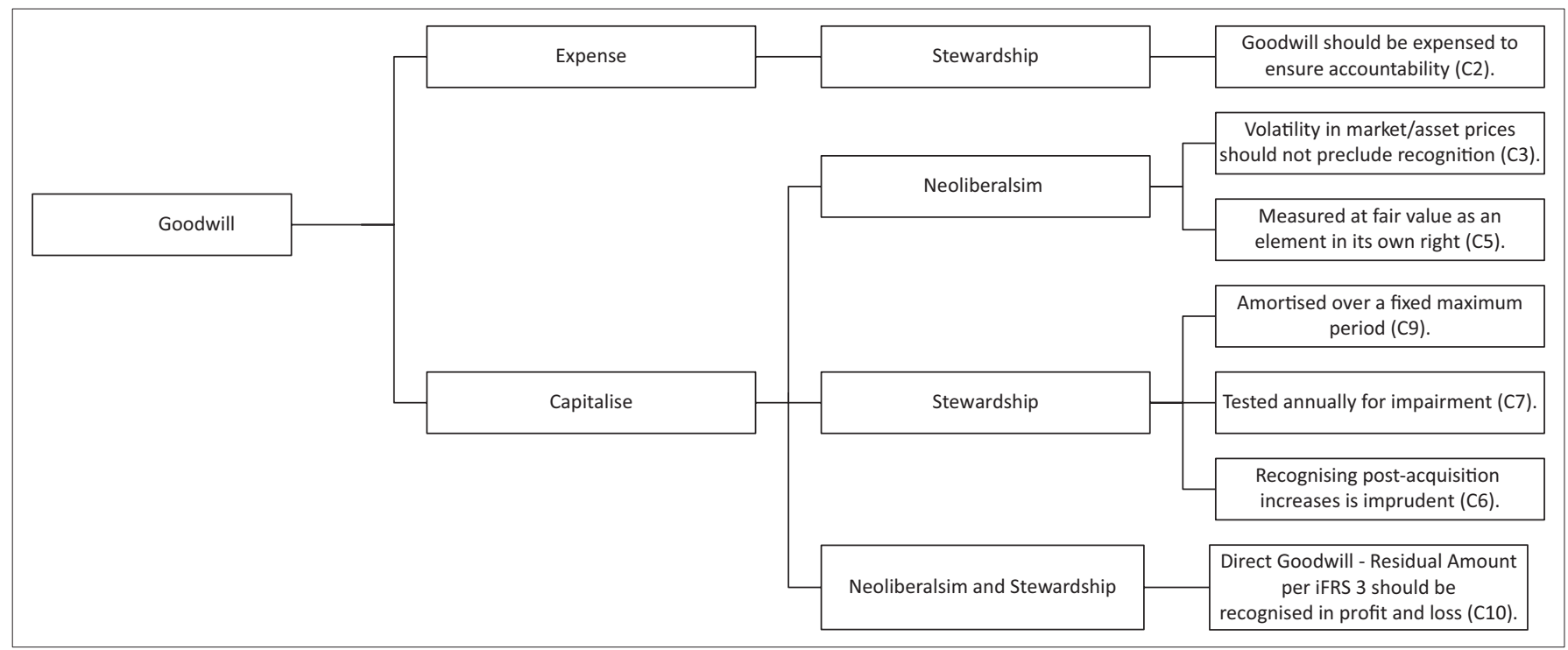

FIGURE 2: Summary of accounting policies.

For the purpose of subsequent measurement, accounting for post-acquisition changes in fair value was seen as imprudent. Goodwill should also be amortised and subject to regular impairment testing in keeping with a stewardship framework and approach suggested by IFRS 3. It appears that, after the business combination has been completed, the primary objective of the accounting system is to communicate the manner in which management has managed the resources entrusted to them and attribute the cost of any assets to profit and loss over time (Ding et al. 2008; Gjesdal 1981; Whittington 2008).

The findings make an important contribution to the academic literature and have a number of implications. Firstly, the article challenges the current accounting practice for recognising and measuring goodwill. The initial recognition of goodwill per IFRS 3 is seldom questioned by practitioners and the possibility of accounting for the difference between direct and indirect measures of goodwill has not been addressed in either the academic or professional literature (Eloff \& De Villiers 2015).

Secondly, the study raises an interesting perspective on how assets are conceptualised by proponents of neoliberal and stewardship paradigms. In terms of IFRS, an asset must result in an inflow of future economic benefits to the reporting entity (IASB 2010). This is interpreted broadly by neoliberalists. They view goodwill as an asset because it is capable of generating synergistic benefits in perpetuity. Uncertainty in the measurement of these benefits is accounted for by incorporating volatility in fair value measures in the income statement (see Barth 2006; Whittington 2008). In contrast, stewardship embraces a narrow temporal focus. Where goodwill is expected to result in synergistic benefits, an asset is recognised. An inherently conservative approach is applied which sees the income-earning potential of goodwill decreasing over time. This erosion of future economic benefits is accounted for by amortising goodwill over a finite period and regularly accounting for impairments. Uncertainty in expected future cash flows is not seen as a measurement problem but as an indication that initial recognition of those cash flows is inappropriate (see Whittington 2008). At an extreme, goodwill may need to be expensed at initial recognition if cash flows are so uncertain that the difference between the purchase price and the value of net identifiable assets is indicative of inefficient bargaining by management, rather than anticipated future synergistic benefits.

Thirdly, rather than seeing neoliberalism and stewardship as opposing paradigms, it may be appropriate to incorporate features of these frameworks in a hybrid accounting model. Goodwill is initially recognised as an asset and measured using the excess profits approach. The difference between the direct measure and the indirect measure required by IFRS 3 is interpreted as a gain or loss and indicates how effectively management has negotiated the acquisition price. Subsequently, the amount initially recognised as an asset is amortised over the period in which management expects reasonably to benefit from the synergistic benefits of the business combination.

\section{Limitations and areas for further research}

The proposed accounting model is a normative one which is not consistent with IFRS 3. As a result, it cannot be applied by practitioners. The proposed accounting is, however, useful for framing an alternate approach to accounting for goodwill which can be considered by the IASB and FASB when revising existing accounting standards. This will require additional research. For example, additional guidance will be required on how to interpret and apply fair value models for goodwill. It is unlikely that a single market price for goodwill can be observed directly, with the result that level 2 and level 3 inputs will need be used (IFRS 2011, 13). The relevant calculations will be subjective and complex, leading to possible understatement or overstatements of goodwill, opportunities for earnings management and a need for additional testing by auditors. Each of these aspects can be considered in more 
detail by researchers interested in evaluating the application of accounting policies in a real-world setting.

Related closely to this, this article deals only with goodwill in the context of a wholly owned subsidiary. It does not deal with goodwill acquired as part of the purchase of a business that is not also a subsidiary or goodwill arising in partly owned subsidiaries. Presentation and disclosure requirements are also outside the scope of this article. These present areas for further research which can yield additional perspectives on the proposed normative accounting policies or the current IFRS 3 treatment.

Finally, this article uses a correspondence analysis informed by the opinions of a group of experts whose focus is on the financial performance of the organisation. Future researchers can examine how differences in the accounting for goodwill vary among stakeholders in order to gain a better understanding of how financial reporting is interpreted by multiple stakeholders with different information needs. This can be complemented by an expanded study dealing with the accounting for other balances and transactions and in different jurisdictions to take into account variations in underlying economic and cultural heuristics.

\section{Acknowledgements Competing interests}

The authors have declared that no competing interests exist.

\section{Authors' contributions}

All authors contributed equally to this work.

\section{Funding information}

This research received no specific grant from any funding agency in the public, commercial or not-for-profit sectors.

\section{Data availability statement}

All data collected from this research study can be made available upon request as data were created by way of this study.

\section{Disclaimer}

The views and opinions expressed in this article are those of the authors and do not necessarily reflect the official policy or positions of any affiliated agency of the authors.

\section{References}

Accounting Standards Board [ASB], 1997, FRS10: Goodwill and intangible assets, Accounting Standards Board, London.

Al Jifri, K. \& Citron, D., 2009, 'The value-relevance of financial statement recognition versus note disclosure: Evidence from goodwill accounting', European Accounting Review 18(1), 123-140. https://doi.org/10.1080/09638180802324351

Baldi, F. \& Trigeorgis, L., 2009, 'Assessing the value of growth option synergies from business combinations and testing for goodwill impairment: A real options perspective', Journal of Applied Corporate Finance 21(4), 115-124. https://doi. org/10.1111/j.1745-6622.2009.00255.x
Barth, M.E., 2006, 'Including estimates of the future in today's financial statements', Accounting Horizons 20(3), 271-285. https://doi.org/10.2308/acch.2006.20.3.271

Beatty, A. \& Weber, J., 2006, 'Accounting discretion in fair value estimates: An examination of SFAS 142 goodwill impairments', Journal of Accounting Research 44(2), 257-288. https://doi.org/10.1111/j.1475-679X.2006.00200.x

Beh, E.J., 2004, 'Simple correspondence analysis: A bibliographic review', International Statistical Review 72(2), 257-284. https://doi.org/10.1111/j.1751-5823.2004. tb00236.x

Bendixen, M., 1996, 'A practical guide to the use of correspondence analysis in marketing research', Marketing Research On-Line 1, 16-36.

Board, F.A.S., 2001, SFAS 142: Accounting for goodwill and intangible assets, FASB, Norwalk, CT.

Broadbent, J. \& Unerman, J., 2011, 'Developing the relevance of the accounting academy: The importance of drawing from the diversity of research approaches', Meditari Accountancy Research 19(1/2), 7-21. https://doi.org/10.1108/10222521111178600

Bugeja, M. \& Gallery, N., 2006, 'Is older goodwill value relevant?', Accounting \& Finance 46(4), 519-535. https://doi.org/10.1111/j.1467-629X.2006.00181.x

Chambers, D.J., 2007, Has goodwill accounting under SFAS 142 improved financial reporting? SSRN: 953649

Chen, J.S., 2001, 'A case study of Korean outbound travelers' destination images by using correspondence analysis', Tourism Management 22(4), 345-350. https:// doi.org/10.1016/S0261-5177(00)00066-2

Ciprian, G.G., Valentin, R., Mădălina, G.I.A. \& Lucia, V.V.M., 2012, 'From visible to hidden intangible assets', Procedia-Social and Behavioral Sciences 62, 682-688. https://doi.org/10.1016/j.sbspro.2012.09.116

Ding Y, Richard, J. \& Stolowy, H., 2008, 'Towards an understanding of the phases of goodwill accounting in four Western capitalist countries: From stakeholder model to shareholder model', Accounting, Organizations and Society 33(7-8), 718-755. https://doi.org/10.1016/j.aos.2007.07.002

Doey, L. \& Kurta, J., 2011, 'Correspondence analysis applied to psychological research', Tutorials in Quantitative Methods for Psychology 7, 5-14. https://doi. org/10.20982/tqmp.07.1.p005

Durocher, S. \& Gendron, Y., 2014, 'Epistemic commitment and cognitive disunity toward fair-value accounting', Accounting and Business Research 44(6), 630-655. https://doi.org/10.1080/00014788.2014.938012

Ellis, M., 2001, Goodwill accounting: Everything has changed and nothing has changed', Journal of Applied Corporate Finance 14(3), 103-112. https://doi. org/10.1111/j.1745-6622.2001.tb00442.x

Eloff, A.-M. \& De Villiers, C., 2015, 'The value-relevance of goodwill reported under IFRS 3 versus IAS 22', South African Journal of Accounting Research 29(2), 162 176. https://doi.org/10.1080/10291954.2015.1006485

Gjesdal, F., 1981, 'Accounting for stewardship', Journal of Accounting Research 19(1), 208-231. https://doi.org/10.2307/2490970

Gore, R. \& Zimmerman, D., 2010, 'Is goodwill an asset?', The CPA Journal 80, 46.

Guest, G., Namey, E. \& Mitchell, M., 2013, 'Defining and designing', in Collecting qualitative data: A field manual for applied research, Chapter 1, Sage, CA, viewed 29 July 2014, from http://www.sagepub.com/upm-data/48453_ch_1. pdf.

Habib, F., Etesam, I., Ghoddusifar, S.H. \& Mohajeri, N., 2012, 'Correspondence analysis: A new method for analyzing qualitative data in architecture', Nexus Network Journal 14, 517-538. https://doi.org/10.1007/s00004-012-0129-1

Hair, J.F., Black, W.C., Babin, B.J., Anderson, R.E. \& Tatham, R.L., 1998, Multivariate data analysis, Prentice hall Upper Saddle River, NJ.

Hoffman, D.L. \& Franke, G.R., 1986, 'Correspondence analysis: Graphical representation of categorical data in marketing research', Journal of Marketing Research 23(3)213-227. https://doi.org/10.1177/002224378602300302

Hopwood, A.G., 1987, 'The archeology of accounting systems', Accounting, Organizations and Society 12(3), 207-234. https://doi.org/10.1016/0361 3682(87)90038-9

Huikku, J., Mouritsen, J. \& Silvola, H., 2017, 'Relative reliability and the recognisable firm: Calculating goodwill impairment value', Accounting, Organizations and Society 56, 68-83. https://doi.org/10.1016/j.aos.2016.03.005

International Accounting Standards Board [IASB], 2004a, International Accounting Standard 36: Impairment of assets, IASB, London.

International Accounting Standards Board [IASB], 2004b, International Financial Reporting Standards 3: Business combinations, IASB, London.

International Accounting Standards Board [IASB], 2007, International Accounting Standards 1: Presentation of financial statements, IASB, London.

International Accounting Standards Board [IASB] 2008, IAS 38: Intangible assets, IASB, London.

International Accounting Standards Board [IASB], 2009, International Financial Reporting Standards 3: Business combinations, IASB, London.

International Accounting Standards Board [IASB], 2010, The conceptual framework for financial reporting, IASB, London.

International Accounting Standards Board [IASB], 2011, International Financia Reporting Standard 13: Fair value measurement, IASB, London.

International Accounting Standards Board [IASB], 2015, IFRS for SME's, IASB, London.

International Accounting Standards Board [IASB], 2016, Goodwill and impairment. AP 18: Cover page and feedback, IASB, London. 
Jahmani, Y., Dowling, W.A. \& Torres, P.D., 2010, 'Goodwill impairment: A new window for earnings management', Journal of Business \& Economics Research 8(2), 19-23. https://doi.org/10.19030/jber.v8i2.669

Johnson, L.T. \& Petrone, K.R., 1998, 'Commentary: Is goodwill an asset?', Accounting Horizons 12(3), 203-303. https://doi.org/10.2139/ssrn.143839

Jordan, C.E. \& Clark, S.J., 2004, 'Big bath earnings management: The case of goodwill impairment under SFAS No. 142', Journal of Applied Business Research 20(2), 6370. https://doi.org/10.19030/jabr.v20i2.2206

Kim, S., Lee, C. \& Wook Yoon, S., 2013, 'Goodwill accounting and asymmetric timeliness of earnings', Review of Accounting and Finance 12(2), 112-129. https:// doi.org/10.1108/14757701311327687

Kudlats, J., Money, A. \& Hair, J.F., 2014, 'Correspondence analysis: A promising technique to interpret qualitative data in family business research', Journal of Family Business Strategy 5, 30-40.

Lee, C., 2011, 'The effect of SFAS 142 on the ability of goodwill to predict future cash flows', Journal of Accounting and Public Policy 30(3), 236-255. https://doi. org/10.1016/j.jaccpubpol.2010.11.001

Lee, C., Kim, S. \& Yoon, S.W., 2013, 'Goodwill accounting and asymmetric timeliness of earnings', Review of Accounting and Finance, 12(2), 112-129. https://doi. org/10.1108/14757701311327687

Ma, R. \& Hopkins, R., 1988, 'Goodwill - An example of puzzle-solving in accounting', Abacus 24(1), 75-85. https://doi.org/10.1111/j.1467-6281.1988.tb00204.

Maroun, W., 2015, 'Reportable irregularities and audit quality: Insights from South Africa', Accounting Forum 39(1), 19-33. https://doi.org/10.1016/j.accfor. 2014.03.002

Maroun, W. \& Garnett, R., 2014, 'The Transnet pipeline case study', Emerald Emerging Markets Case Studies 4(7), 1-27. https://doi.org/10.1108/EEMCS-01 2014-0009

Maroun, W., Turner, M. \& Sartorius, K., 2011, 'Does capital gains tax add to or detract from the fairness of the South African tax system?', South African Journal of Economic and Management Sciences 14(4), 436-448. https://doi.org/10.4102/ sajems.v14i4.131

Martínez, A.A. \& Rubio, J.A.C., 2018, 'The economic effects of IFRS goodwill reporting', Australian Accounting Review 28(3), 309-322. https://doi.org/10.1111/auar 12200

Murphy, T., O'Connell, V. \& O'Hógartaigh, C., 2013, 'Discourses surrounding the evolution of the IASB/FASB conceptual framework: What they reveal about the "living law" of accounting', Accounting, Organizations and Society 38(1), 72-91. https://doi.org/10.1016/j.aos.2012.07.003

Negash, M., 2003, 'Rethinking the reporting of intangibles', South African Journal of Accounting Research 17, 23-40.
Ormrod, L.A., 2014, 'Practical research', American International Journal of Contemporary Research 4(5), 47-55.

Qasim, A., Haddad, A.E. \& Abughazaleh, N.M., 2013, 'Goodwill accounting in the United Kingdom: The effect of international financial reporting standards' Review of Business \& Finance Studies 4(1), 63-78.

Ram, A., Maroun, W. \& Garnett, R., 2016, 'Accounting for the Bitcoin: Accountability, neoliberalism and a correspondence analysis', Meditari Accountancy Research 24(1), 2-35. https://doi.org/10.1108/MEDAR-07-2015-0035

Ramanna, K. \& Watts, R.L., 2012, 'Evidence on the use of unverifiable estimates in required goodwill impairment', Review of Accounting Studies 17, 749-780. https://doi.org/10.1007/s11142-012-9188-5

Ravenscroft, S. \& Williams, P.F., 2009, 'Making imaginary worlds real: The case of expensing employee stock options', Accounting, Organizations and Society $34(6-7)$ 770-786. https://doi.org/10.1016/j.aos.2008.12.001

Saunders, M., Lewis, P. \& Thornhill, A., 2009, Research methods for business students, 5th edn., Pearson Education Ltd, Essex.

Savčuk, O., 2007, 'Internal audit efficiency evaluation principles', Journal of Business Economics and Management 8(4), 275-284. https://doi.org/10.3846/16111699.2 007.9636180

Shalev, R., Zhang, I.X. \& Zhang, Y., 2013, 'CEO compensation and fair value accounting: Evidence from purchase price allocation', Journal of Accounting Research 51(4), 819-854. https://doi.org/10.1111/1475-679X.12015

Sinclair, R., 2007, 'The goals of goodwill', Journal of Marketing 71(3), 30-32.

Steenekamp, T.J., 1996, 'Some aspects of corporate taxation in South Africa: The Katz commission', South African Journal of Economics 64(1), 1-19. https://doi. org/10.1111/j.1813-6982.1996.tb01111.x

Su, W.H. \& Wells, P., 2014, 'The association of identifiable intangible assets acquired and recognised in business acquisitions with postacquisition firm performance', Accounting \& Finance 55(4), 1171-1199. https://doi.org/10.1111/acfi.12086

Watts, R. \& Zimmerman, J., 1979, 'The demand for and supply of accounting theories: The market for excuses', The Accounting Review 54, 273-305.

Watts, R.L. \& Zimmerman, J.L., 1978, 'Towards a positive theory of the determination of accounting standards', Accounting Review 53(3), 112-134.

Whittington, G., 2008, 'Fair value and the IASB/FASB conceptual framework project: An alternative view', Abacus 44(2), 139-168. https://doi.org/10.1111/j.14676281.2008.00255.x

Young, R.A., 1998, The stewardship role of accounting, Unpublished notes, The Ohio State University, Columbus, $\mathrm{OH}$.

Zhang, Y. \& Andrew, J., 2014, 'Financialisation and the conceptual framework', Critical Perspectives on Accounting 25(1), 17-26. https://doi.org/10.1016/j.cpa.2012.11.012 


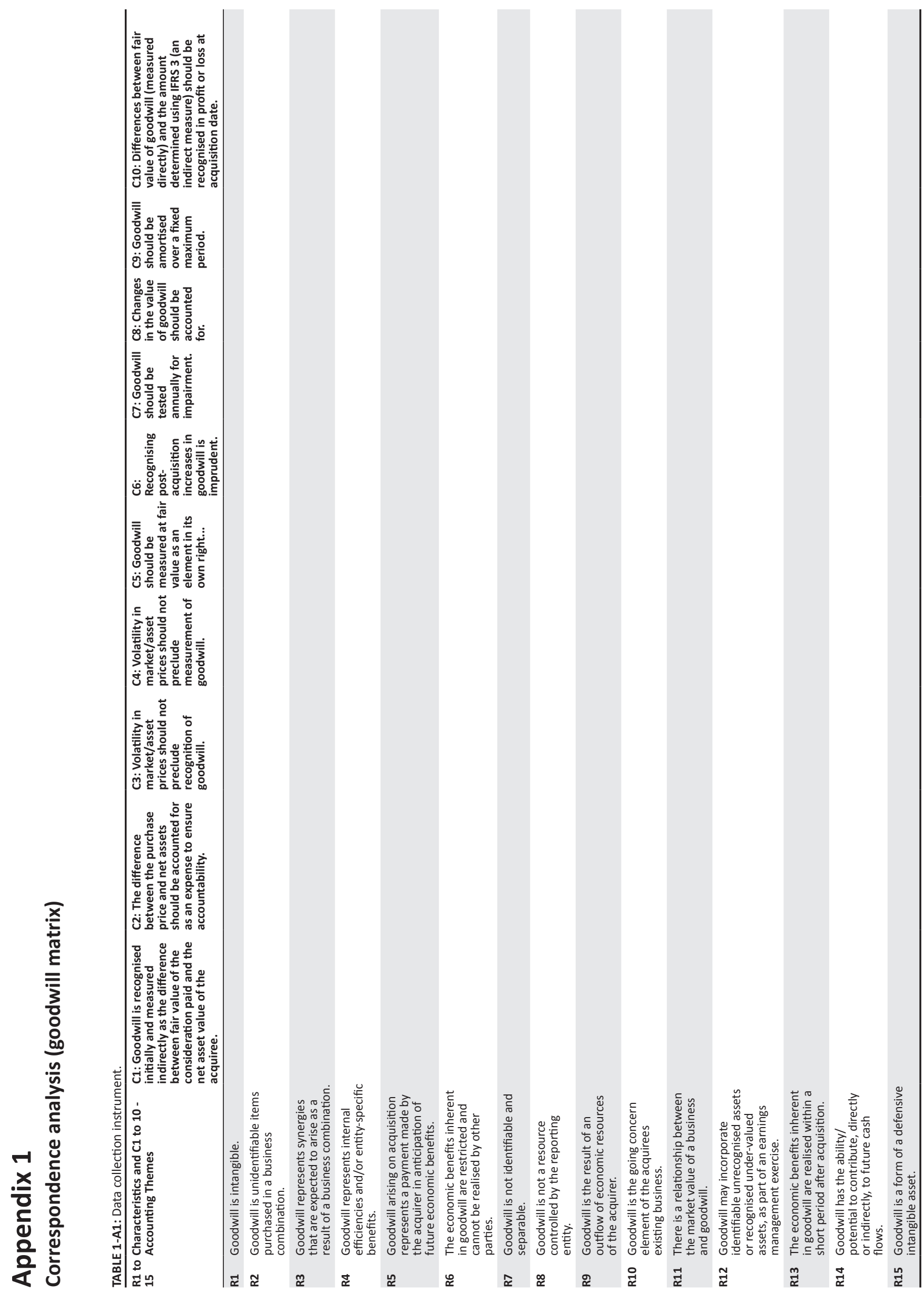




\section{Appendix 2}

\section{Statistics for goodwill characteristics}

Table 1-A2 represents the statistics relating to the characteristics of the goodwill (rows) in the correspondence table. Each characteristic has a coordinate in both Dimension 1 and Dimension 2, with the contribution ('contrib') showing the relative strength of the characteristics in the overall relationship. A higher contribution indicates a greater strength and, therefore, increasing statistical significance.

TABLE 1-A2: Statistics for characteristics of goodwill.

\begin{tabular}{|c|c|c|c|c|c|c|c|c|c|}
\hline \multirow[t]{2}{*}{ Categories: Rows } & \multicolumn{3}{|c|}{ Overall } & \multicolumn{3}{|c|}{ Dimension 1 ( $x$-axis) } & \multicolumn{3}{|c|}{ Dimension 2 ( $y$-axis) } \\
\hline & Mass & Quality & \%inertia & Coord & Sqcorr & Contrib & Coord & Sqcorr & Contrib \\
\hline R 1 & 0.081 & 0.661 & 0.047 & 0.284 & 0.316 & 0.022 & 0.448 & 0.344 & 0.125 \\
\hline R 2 & 0.081 & 0.347 & 0.03 & -0.217 & 0.289 & 0.013 & 0.148 & 0.059 & 0.014 \\
\hline R 3 & 0.091 & 0.565 & 0.025 & 0.261 & 0.559 & 0.021 & -0.041 & 0.006 & 0.001 \\
\hline R 4 & 0.077 & 0.733 & 0.027 & 0.333 & 0.722 & 0.029 & -0.062 & 0.011 & 0.002 \\
\hline R 5 & 0.088 & 0.449 & 0.03 & 0.185 & 0.231 & 0.01 & -0.272 & 0.218 & 0.05 \\
\hline R 7 & 0.057 & 0.922 & 0.08 & -0.749 & 0.912 & 0.107 & 0.117 & 0.01 & 0.006 \\
\hline R 8 & 0.043 & 0.966 & 0.263 & -1.604 & 0.955 & 0.369 & -0.253 & 0.01 & 0.021 \\
\hline R 9 & 0.052 & 0.964 & 0.154 & -1.065 & 0.877 & 0.198 & -0.506 & 0.087 & 0.103 \\
\hline R 10 & 0.052 & 0.743 & 0.024 & 0.385 & 0.74 & 0.026 & -0.04 & 0.004 & 0.001 \\
\hline R 11 & 0.084 & 0.815 & 0.117 & 0.554 & 0.505 & 0.087 & -0.658 & 0.31 & 0.281 \\
\hline R 12 & 0.063 & 0.207 & 0.008 & 0.074 & 0.096 & 0.001 & 0.121 & 0.111 & 0.007 \\
\hline R 13 & 0.048 & 0.661 & 0.096 & -0.492 & 0.278 & 0.039 & 0.874 & 0.383 & 0.284 \\
\hline R 15 & 0.044 & 0.375 & 0.019 & 0.071 & 0.027 & 0.001 & 0.39 & 0.349 & 0.052 \\
\hline
\end{tabular}




\section{Appendix 3}

\section{Statistics for goodwill accounting themes}

Table 1-A3 represents the statistics relating to the accounting policy themes (columns) in the correspondence table. Each accounting policy has a coordinate in both Dimension 1 and Dimension 2, with the contribution ('contrib') showing the relative strength of the accounting policy to the overall relationship. A higher contribution indicates a greater strength and, therefore, increasing statistical significance.

TABLE 1-A3: Statistics for accounting policy themes.

\begin{tabular}{|c|c|c|c|c|c|c|c|c|c|}
\hline \multirow[t]{2}{*}{ Categories: Rows } & \multicolumn{3}{|c|}{ Overall } & \multicolumn{3}{|c|}{ Dimension 1 ( $x$-axis) } & \multicolumn{3}{|c|}{ Dimension 2 ( $y$-axis) } \\
\hline & Mass & Quality & \%inertia & Coord & Sqcorr & Contrib & Coord & Sqcorr & Contrib \\
\hline C 1 & 0.161 & 0.065 & 0.064 & 0.025 & 0.004 & 0 & -0.157 & 0.062 & 0.03 \\
\hline$C 2$ & 0.088 & 0.985 & 0.378 & -1.361 & 0.984 & 0.547 & -0.064 & 0.001 & 0.003 \\
\hline C 3 & 0.11 & 0.814 & 0.067 & 0.374 & 0.525 & 0.052 & -0.421 & 0.29 & 0.151 \\
\hline C 4 & 0.113 & 0.742 & 0.057 & 0.358 & 0.586 & 0.049 & -0.28 & 0.156 & 0.068 \\
\hline C 5 & 0.105 & 0.843 & 0.09 & 0.563 & 0.842 & 0.112 & -0.039 & 0.002 & 0.001 \\
\hline C 6 & 0.08 & 0.874 & 0.053 & -0.454 & 0.705 & 0.055 & 0.337 & 0.17 & 0.07 \\
\hline C 7 & 0.118 & 0.551 & 0.048 & 0.217 & 0.263 & 0.019 & 0.343 & 0.288 & 0.107 \\
\hline C 8 & 0.093 & 0.799 & 0.058 & 0.432 & 0.685 & 0.058 & 0.267 & 0.115 & 0.051 \\
\hline C9 & 0.047 & 0.749 & 0.076 & -0.04 & 0.002 & 0 & 1.094 & 0.747 & 0.436 \\
\hline C 10 & 0.086 & 0.777 & 0.109 & -0.614 & 0.677 & 0.109 & -0.357 & 0.1 & 0.084 \\
\hline
\end{tabular}

